\title{
Regulation of the vitamin $D$ receptor and cornifin beta expression in vaginal epithelium of the rats through vitamin $D_{3}$
}

\author{
G. Abban, ${ }^{1}$ N.B.Yildirim, ${ }^{2}$ A.M. Jetten ${ }^{3}$ \\ ${ }^{1}$ Department of Histology and Embryology, School of Medicine and ${ }^{2}$ Department of Obstetrics and \\ Gynecology, Faculty of Medicine, Pamukkale University, Denizli, Turkey; ${ }^{3}$ Cell Biology Section, Laboratory \\ of Pulmonary Pathobiology, NIEHS, NIH Research Triangle Park, Nc, USA
}

C2008 European Journal of Histochemistry

The aim of the present study was to determine the respective role of 1,25-dihydroxyvitamin $D_{3}$ on vaginal epithelium and 1,25-dihydroxyvitamin D3 receptor expression in ovariectomized rats and vitamin $\mathrm{D}_{3}$ treated rats. Bilateral ovariectomies were performed in 20 mature, non-pregnant Wistar female rats. All the animals were divided into 2 groups consisting of 10 rats each. Group I served as control. In group II, animals were injected intramuscularly with vitamin D3 (50, $00 \mathrm{lU} / \mathrm{kg})$. Two weeks after the injections, vaginas of animals in group I and group II were removed removed and processed for immunohistochemistry. Epithelial differentiation, 1,25-dihydroxyvitamin $D_{3}$ receptor and cornifin $\beta$ expression were investigated in vaginal epithelium of control group (ovariectomized) and vitamin $\mathrm{D}_{3}$ treated rats. Vaginal epithelial cells from vitamin $D_{3}$ treated animals changed into highly- stratified keratinizing layers. 1,25-dihydroxyvitamin $D_{3}$ receptor and cornifin $\beta$ as a marker of squamous differentiation were present in ovariectomized rats treated with 1,25dihydroxyvitamin $D_{3}$. In contrast, cornifin $\beta$ and 1,25-dihydroxyvitamin $D_{3}$ receptor were absent in all layers of vaginal epithelium in control group. We demonstrated for the first time that 1,25 -dihydroxyvitamin $D_{3}$ induced proliferation of vaginal epithelium consistent with the cornifin $\beta$ expression and 1,25-dihydroxyvitamin $\mathrm{D}_{3}$ up-regulated 1,25-dihydroxyvitamin D3 receptor expression in vaginal epithelium.

Key words: vitamin $D$, vagina, cornifin $\beta$, vitamin $D$ receptor.

Correspondence: Gulcin Abban,

Pamukkale University Medical School

Histology and Embryology Department

Kinikli, Denizli, Turkey.

Tel.: +90.258.2952472.

Fax: +90.258 .2952444$

E-mail: gabban@pau.edu.tr

Paper accepted on May 27, 2008

European Journal of Histochemistry

2008; vol. 52 issue 2 (Apr-Jun): 107-114
V agina which is surrounded by squamous, stratified epithelium is under the effect of estrogen hormone. It causes various complaints for women in menopouse, that is to say, in the absence of estrogen hormone. Vaginal dryness or atrophic vaginitis, also referred to as urogenital atrophy, is a common problem for postmenopausal women. The most common symptoms are dryness, burning, pruritus, irritation and dyspareunia, thus leading to decreased libido and quality of life (Notelovitz 2002).

Estrogen treatment in post menopausal women has been shown to increase collagen content, dermal thickness and elasticity. Biophysical properties are also significantly improved for the parameters reflecting hydration and sebum secretion (CasteloBranco C 2005). However, numerous side effects such as increased incidence of cancer and cardiovascular morbidity limit the use of this treatment (Nohales 2006, Gniadecki 1996, Berger 1988). Unlike the systemic estrogen treatment, which has adverse effects such as bleeding, cancer risk, cardiovascular system problems, local oestrogen treatment has no such side effects. However, many women consider pessaries and creams to be messy, and application times difficult to remember (Suckling J 2003 Cicinelli $E$ 2008). For this reason, to get rid of the menopausal complaints, new alternative treatment methods are needed. Vitamin D (1,25-dihydroksivitamin D3) is a promoter of keratinocyte differentiation and a modulator of keratinocyte proliferation in the epidermis (Bikle 2007). Like the skin, vagina is also surrounded by a stratified squamous epithelium. The hypothesis of if vitamin D can enhance proliferation and differentiation of skin epithelium could it be possible to have the same effect on vaginal epithelium is the base of this study.

1,25-dihydroxyvitamin D3 $\left(1,25(\mathrm{OH})_{2} \mathrm{D}_{3}\right.$, Calcitriol) is a pleiotropic hormone with proliferative, pro-apoptotic and pro-differentiation effects on numerous cell types, in addition to its classical reg- 
ulatory action on calcium and phosphate metabolism (Bikle 2007, De Luca 2004). 1,25(OH) ${ }_{2} \mathrm{D}_{3}$ would have important implications for the aetiology and therapy of various diseases, such as cancer, diabetes mellitus and psoriasis (Liu 1996, Holick 2006, Park 2000, Guzey 2002, Pepper 2003, Fischer 2007, Mordan- McCombs 2007, Ginanjar 2007, Arnson 2007, Pittas 2007, Lebwohl 2007, Zhu 2007).

The biological effects of 1,25-dihydroxyvitamin $D_{3}\left(1,25(\mathrm{OH})_{2} D_{3}\right)$ are mediated by its nuclear receptor (Petrazzouli 1999). $1,25(\mathrm{OH})_{2} \mathrm{D}_{3}$ interacts with its intracellular receptor [vitamin $D$ receptor (VDR)] to induce the expression of a variety of genes (Kutuzova 2004, White 2004). These genes are important in the regulation of growth and differentiation of a stratified squamous epithelium. In our earlier study, for the first time the presence of VDR in vaginal epithelium was demonstrated. VDR was preferentially localized in basal and suprabasal layers, where cells undergo proliferation and differentiation. VDR expression in vaginal epithelium changed during the estrus cycle. In ovariectomized rats, VDR was absent from all layers of vaginal epithelium (Yildirim 2004).

Squamous differentiation is a multi-stage process in which each step is characterized by the expression of specific genes, including those encoding various keratins and proteins involved in formation of cross linked envelope. Cornifins or human small proline- rich proteins (SPRR's) are family of crosslinked envelope precursor proteins (Jetten 1992 a, Gijbels 1992, Darwiche 1993, Gibbs 1993). Preliminary studies have indicated that the levels of cornifin expression change with a higher stage of malignancy of the cervical epithelium, and support the idea that cornifin could be a good marker to monitor the stage of malignancy in the female reproductive tract (Jetten 1996 b). In this study cornifin $\beta$ was used as a marker to determine the squamouse differentiation in overiectomized and vitamin D3 treated vaginal epitehelium.

In this study we searched the answers for two questions. First one is, whether vitamin $D$ has an effect on reshaping the vaginal epithelium and if so, does it create this effect through the vitamin $D$ receptors. The second is whether the vitamin $D$ affects the cornifin $\beta$ expression. We have found that in the vitamin D applied group, after ovariectomization, the epithelial was reshaped and the expressions of cornifin $\beta$ and VDR increased.

\section{Materials and Methods}

\section{Animals}

Twenty adult non-pregnant Wistar female rats were used. They were housed in temperature-controlled rooms $\left(27 \pm 10^{\circ} \mathrm{C}\right)$ at light/dark $14 / 10 \mathrm{~h} \mathrm{reg-}$ imen. Estrous cyclity was monitored by cytological examination of vaginal smears taken between 08:30 and 09:30 a.m 5 days a week. Only those females that experienced two regular 4-day cycles consisting of 2-day diestrus, 1-day proestrus and 1day estrus were used. We followed the ethical guidelines for the treatment of laboratory animals.

\section{Tissue collection}

Bilateral ovariectomy was performed in all mature non-pregnant Wistar rats. All the animals were divided into 2 groups consisting of 10 rats each. Group I served as control. In group II, animals were injected intramuscularly with vitamin D3 (50, $00 \mathrm{IU} / \mathrm{kg})$. Two weeks after the injections, vaginas of animals in group I and group II were removed under pentobarbital anesthesia and the rats were sacrificed. Tissues were fixed in 10\% neutral buffered formalin for $72 \mathrm{~h}$ and then embedded in paraffin. Paraffin sections ( $5 \mu \mathrm{m}$ ) were deparaffinized in xylene and rehydrated through a graded series of ethanol solutions.

\section{Histochemistry}

Three sections from each animal were processed by immunocytochemical assay for the expression of VDR and cornifin $\beta$. Human epidermis was used as positive control. Omitting the primary antibody performed negative control.

\section{Antibodies and staining procedure for Vitamin D receptor}

Endogenous peroxidase activity was blocked by $3 \%$ hydrogen peroxidase for 10 minutes and the sections were incubated with saponin to facilitate binding of primary antibody to the antigenic areas. Epitopes were stabilized by application of serum blocking solution (Goat serum, Lot\# 20570999, Zymed Laboratories Inc., San Francisco, USA) for 20 min at room temperature. Sections were incubated overnight with VDR primary antibody (Lot\# 1039, sc 1009 polyclonal antibody, Santa Cruz Biotechnology) diluted $1: 100$ in PBS at $+4^{\circ} \mathrm{C}$. After applying the secondary antibody anti-rabbit Ig, avidin-biotin-complex-peroxidase ( $A B C$, Lot\# 
20570999, Zymed Laboratories Inc.) was applied to the slides. Diaminobenzidine (DAB, Lot\# 10163354, Zymed Laboratories Inc.) was used as chromogen. Afterwards, slides were counterstained with hematoxyline for 1 minute, dehydrated in graded ethanol and mounted in conventional medium.

\section{Antibodies and staining procedure for cornifin $\beta$}

Endogenous peroxidase activity was blocked in $3 \%$ hydrogen peroxidase for 10 minutes and the sections were incubated with saponin to help binding of primer antibody to the antigenic areas. Epitopes were stabilized by application of serum blocking solution (Goat serum, Lot\# 20570999, Zymed Laboratories Inc) for $60 \mathrm{~min}$ at room temperature. Sections were incubated with 1:1000 diluted cornifin $\beta$ primer antibody (SQ37A-Ab, Jetten Laboratories) in PBS at room temperature for $60 \mathrm{~min}$. Then secondary antibody anti-rabbit Ig, avidin-biotin-complex-peroxidase (ABC, Lot\# 20570999, Zymed Laboratories Inc.) were applied on tissue slides. Diaminobenzidine (DAB, Lot\# 10163354, Zymed Laboratories Inc) was used as chromogen. Afterwards, slides were counterstained with hematoxylene for $1 \mathrm{~min}$, dehydrated in graded ethanol and mounted in conventional medium.

Three experienced histologists examined slides for VDR and cornifin $\beta$. The intensity of immuno-reaction was semi quantitatively evaluated which was expressed as intensive $(+++)$, moderate $(++)$, weak $(+)$ and negative (-).

\section{Statistical analysis}

All data were presented as mean \pm standard deviation (S.D.). A computer program (SPSS 12.0 for Windows, SPSS Inc., Chicago, IL, USA) was used for statistical analysis. The data were considered to be non-parametric, therefore, they were analyzed using Mann-Whitney $U$-test. $p<0.05$ were considered to be statistically significant.

\section{Results}

Effect of vitamin $D_{3}$ on epithelial morphology: The atrophic vaginal epithelium of the ovariectomized rats was only $2-3$ cell layers thick (Figure IA). In response to $1,25(\mathrm{OH})_{2} \mathrm{D}_{3}$, basal epithelial cells proliferated rapidly, leading to the formation of a highly stratified epithelium (Figure 1B). The suprabasal cells, which were no longer mitotic, underwent a well-characterized differentiative sequence as they moved up through the epithelium; they became enlarged and underwent structural and morphological changes towards cornification, so that the apical layer became keratinized.

\section{Effect of vitamin $D_{3}$ on Vitamin $D$ receptor expres- sion}

In ovariectomized rats the effect of $1,25(\mathrm{OH})_{2} \mathrm{D}_{3}$, on VDR expression in rat vaginal epithelium was investigated. Figure $2 \mathrm{~A}$ and $\mathrm{B}$ shows the absence of VDR and cornifin $\beta$ in ovariectomized rat epithelium before $1,25(\mathrm{OH})_{2} \mathrm{D}_{3}$, treatment. $V D R$ regulation was tested after 1,25(OH)2D3 injection. The distribution and localization of VDR in vaginal epithelium of rats treated with $1,25(\mathrm{OH})_{2} \mathrm{D}_{3}$ was shown in Figure 3. Prominent nuclear and cytoplasmic immunostaining of VDR was observed in vaginal epithelium. We found that basal, suprabasal and apical cell layers exhibited a positive VDR reaction, but suprabasal and apical cells of vaginal epihelium demonstrated more diffuse and stronger immunostaining for the VDR compared to basal cells. Nuclei of epithelial cells were positive. A slightly positive immunoreaction was noticed in basal membrane (Figure 3 ).

\section{Effect of vitamin D on cornifin $\beta$ expression}

In vagina of ovariectomized mice, stratification occured two weeks after $1,25(\mathrm{OH})_{2} \mathrm{D}_{3}$ injection (Figure 1B). Immunohistochemical staining for cornifin $\beta$ was very intense in the suprabasal and apical layers (Figure 4). Stronger immunostaining was determined in the cell membrane than cytoplasm in the suprabasal and apical cells. A weak immunohistochemical staining was observed in basal cell and basal membrane. While nuclei of apical cells showed strong immunostaining for cornifin $\beta$, no immunostaining was observed in the nuclei of basal cells . Cornified layer was strong negative for cornifin $\beta$ (Figure 4).

Expression of cornifin $\beta$ decreased in ovariectomized rat epithelium compared with the vitamin D3 treated rat epithelium layer $(p<0.05)$, except basal cells of the epithelial cells $(p>0.05)$ (Figure $5)$. However cornifin $\beta$ increased in basal membrane in ovariectomized rats. Like cornifin $\beta$ expression, decrease of the vitamin $D$ receptor was significant in ovariectomized rat epithelium compared with the vitamin D3 treated rat epithelium layer $(p<0.05)$ except basal membrane and cornified layer ( $p>0.05$ ) (Figure 6). 

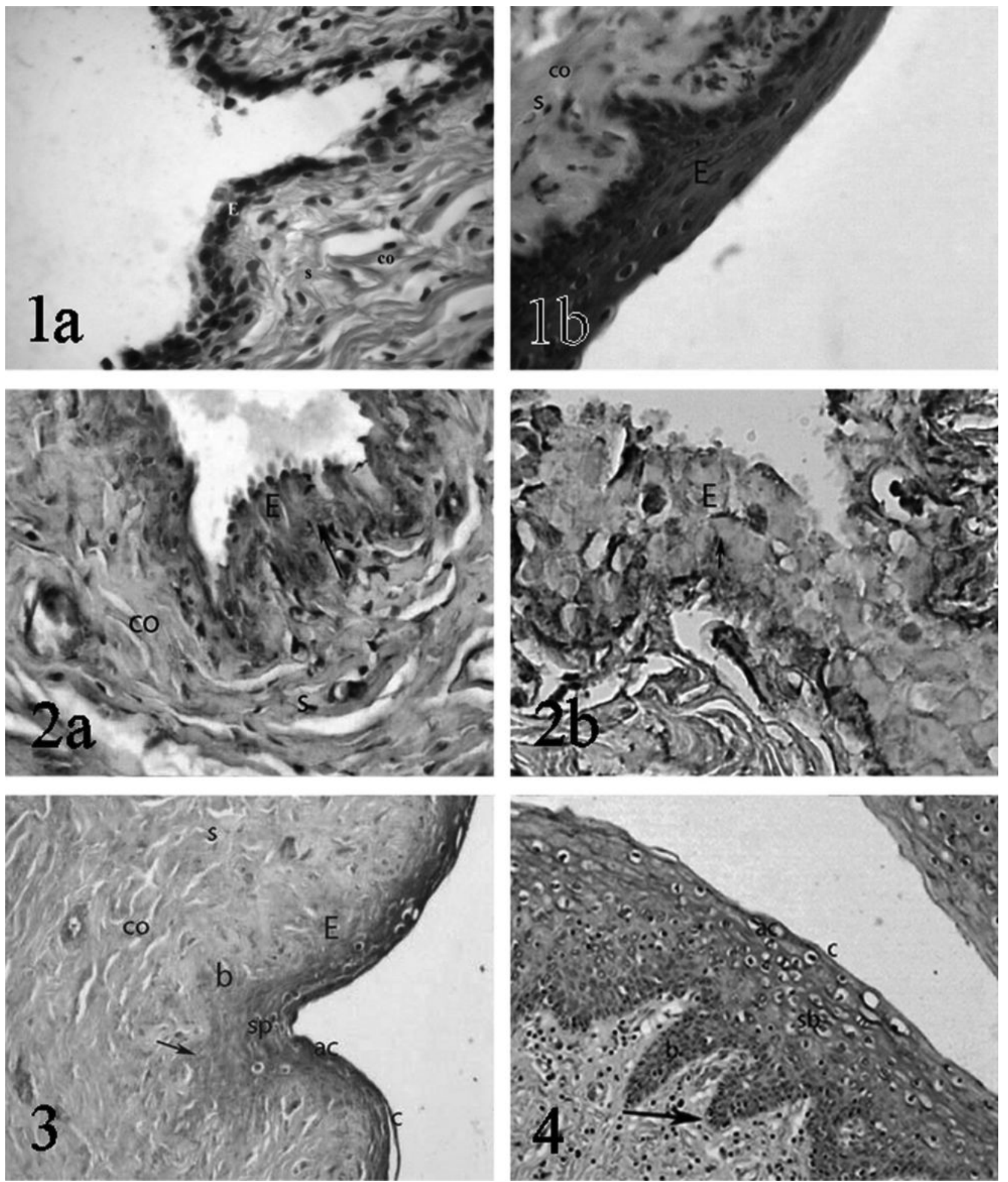

Figure 1. Histological changes in the vaginal epithelium upon treatment with vitamin D3. (A) Ovariectomized vaginal epithelium; (B) vitamin $\mathrm{D}_{3}$ treated vaginal epithelium. E: Epithelium; arrow: basal membrane; co: collagen fibers; s: stromal cells. Hematoxyline-Eosin, magnification: X400.

Figure 2. Negative immunostaining of VDR (A); and cornifin $\beta(B)$ in the vaginal epithelium of ovariectomized rats (B). E: Epithelium; arrow, basal membrane; co: collagen fibers; s: stromal cells. Immunoperoxidase, magnification: X 400.

Figure 3. Immunohistochemical detection of VDR in vaginal epithelium treated with vitamin $\mathrm{D}_{3}$. Positive VDR immunostaining in basal, suprabasal and apical cells. E: Epithelium; arrow: basal membrane; co: collagen fibers; s: stromal cells; b: basal cells; sp: suprabasal cells; ac: apical cells: c: cornified layer. Immunoperoxidase, magnification: X 200.

Figure 4. Immunohistochemical detection of cornifin $\beta$ in vaginal tissue treated with vitamin $D_{3}$. Positive cornifin , immunostaining in suprabasal and apical cells. E: Epithelium; arrow: basal membrane; co: collagen fibers; s: stromal cells; b: basal cells; sp: suprabasal cells; ac: apical cells: c: cornified layer. Immunoperoxidase, magnification: x 200. 
Table 1. Localization and distribution vitamin $D$ receptor in vaginal epithelium.

\begin{tabular}{|c|c|c|c|c|c|c|c|}
\hline & Cornified layer & Apical cells & Suprabasal cells & Basal cells & Basal membran & $\begin{array}{c}\text { Nucleus } \\
\text { (apical cell) }\end{array}$ & $\begin{array}{c}\text { Nucleus } \\
\text { (basal cell) }\end{array}$ \\
\hline Ovariectomized & - & - & - & - & $-/+$ & - & - \\
\hline Vitamin D Treated & _- & +++ & +++ & ++ & $-1+$ & +++ & ++ \\
\hline
\end{tabular}

Table 2. Localization and distribution cornifin $\beta$ in vaginal epithelium.

$\begin{array}{cccccc}\text { Cornified layer Apical cells } & \text { Suprabasal cells } & \text { Basal cells } & \text { Basal membran } & \begin{array}{c}\text { Nucleus } \\ \text { (apical cell) }\end{array} & \begin{array}{c}\text { Nucleus } \\ \text { (basal cell) }\end{array}\end{array}$

\begin{tabular}{llllll}
\hline Ovariectomized & - & - & - & - & +++ \\
Vitamin D Treated & $-1+$ & $+++*$ & $++/+++*$ & + & $-1+$ \\
\hline
\end{tabular}

* Stronger immunostaining was determined in the cell membrane than cytoplasm in the suprabasal and apical cells

Table 3. Expression cornifin $\beta$ in vaginal epithelium.

\begin{tabular}{ccccccc} 
& Cornified layer & Apical cells & Suprabasal cells & Basal cells & $\begin{array}{c}\text { Basal membran } \\
\text { Nucleus } \\
\text { (apical cell) }\end{array}$ & $\begin{array}{c}\text { Nucleus } \\
\text { (basal cell) }\end{array}$ \\
\hline$p$ & 0,029 & 0,00 & 0,00 & 0,00 & $0,00 \quad 0,00$ \\
\hline
\end{tabular}

Test is significant if $p \leq 0,05$

Table 4. Expression vitamin D receptor in vaginal epithelium.

\begin{tabular}{cccccccc}
\hline & Cornified layer & Apical cells & Suprabasal cells & Basal cells & $\begin{array}{c}\text { Basal membran } \\
\text { Nucleus } \\
\text { (apical cell) }\end{array}$ \\
\hline$p$ & 1 & 0,00 & 0,00 & 0,00 & 0,38 & 0,00 \\
\hline
\end{tabular}

\section{cornifin beta expression}

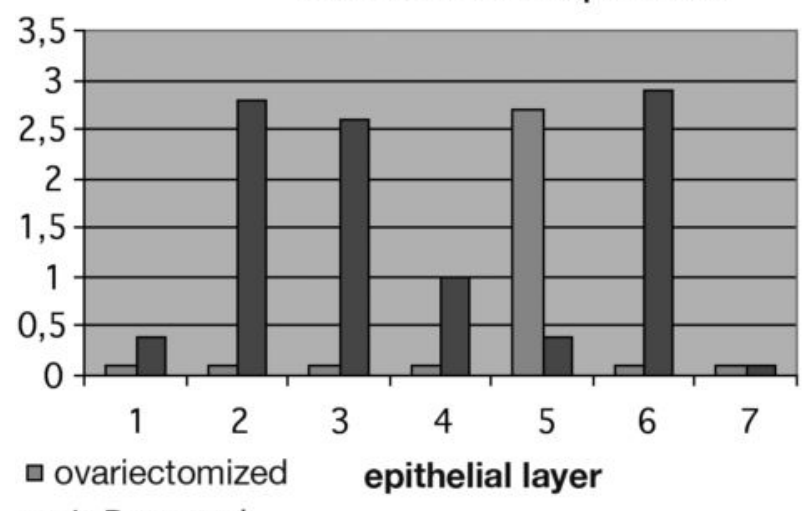

$\square$ vit D treated

Figure 5. Expression of cornifin $\beta$ in ovariectomized rats and vitamin $D$ treated group. 1; cornified layer ${ }^{*} p<0.05,2$; apical cells, ${ }^{*} p<0.05$, 3 ; suprabasal cells $p<0.05$, 4; basal cells, $p$ $<0.05$, 5; basal membran, $p<0.05,6$; apical nucleus, $p<0.05$, 7; basal nucleus, $p>0.05$

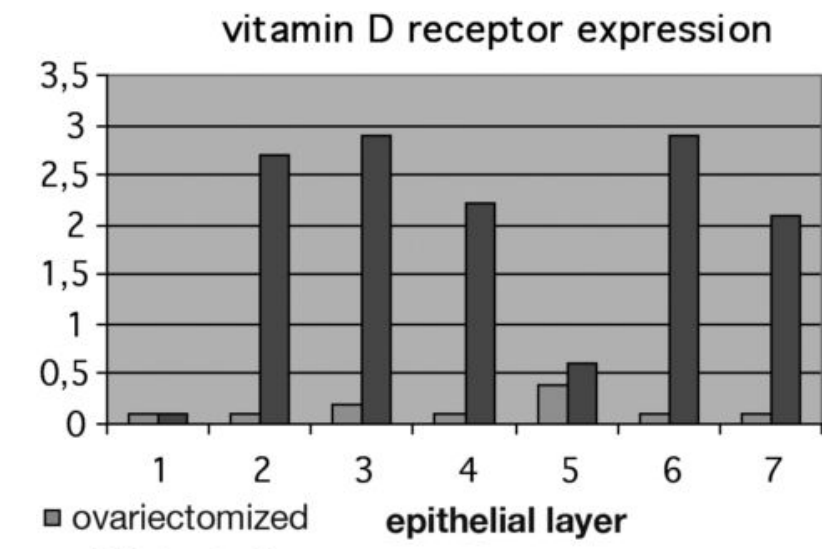

avit $\mathrm{D}$ treated

Figure 6. Expression of vitamin $D$ receptor in ovariectomized rats and vitamin $D$ treated group. 1; cornified layer ${ }^{*} p<0.05,2$; apical cells, $" p<0.05$, 3 ; suprabasal cells $p<0.05$, 4 ; basal cells, $p<0.05,5$; basal membran, $p<0.05,6$; apical nucleus, $p<0.05,7$; basal nucleus, $p>0.05$ 


\section{Discussion}

The use of vitamin $D$ for the therapy of vaginal atrophy can be an emerging new treatment modality. To gain insight into the effect of $1,25(\mathrm{OH})_{2} \mathrm{D}_{3}$ on vaginal epithelization we used ovariectomized rats with vaginal tissue deprived of functional estrogen. And also we used cornifin $\beta$ as a marker of vaginal epithelial differentiation. The other aim of the present study was to determine the respective role of $1,25(\mathrm{OH})_{2} \mathrm{D}_{3}$ on VDR and cornifin $\beta$ expression in vaginal epithelium.

Menopause is the lasting cessation of menstruation because of the loss of follicular activity. There comes some changes in menopausal woman: pubic hair grays and becomes sparse, the labia majora lose subcutaneous fat, and the labia minora, vestibule, and vaginal mucosa atrophy (Jones 1983, Erickson 1972). Menopausal and post-menopausal atrophic vulvovaginitis is an almost common condition. The decrease in vaginal secretions reduces lubrication and increases coital discomfort. Thinned tissue is more easily irritated and may be more vulnerable to infection. The prevalence of colonization by enteric organisms associated with urinary tract infections increases due to the rise of vaginal $\mathrm{pH}$ (Fischer 1998). In addition to these physiologically induced changes, certain vulvar dermatoses, such as lichen sclerosus, are most common postmenopausal women (Kamarashev 1997).

In the absence of estradiol, vaginal epithelium was shown to be atrophic, and consisted of 2-3 layers of squamous epithelial cells as we demonstrated experimentally in this study.

Atrophic vaginitis can be treated with estrogen therapy. Notably, estrogen is also considered to increase the risk of developing breast cancer. It improved susceptibility to estradiol (Wadia 2007), decreased apoptosis, and increased the number of progesterone receptor-positive epithelial cells (Mun?oz-de-Toro 2007). There is a large group of epidemiological and experimental evidence that estrogens are strongly implicated in the aetiology of some carcinomas requiring oestrogen for continued growth and progression (Henderson 1990, Henderson 1988). Nowadays, as an alternative to systemic estrogen treatment, local estrogen treatment is being applied. Of course, Replens, a nonhormonal alternative treatment to oestrogen replacement treatment, overcomes the symptoms caused by vaginal atrophy (Van der Laak JA.
2002). Although the local estrogen treatment does not have adverse effects such as bleeding, cancer risk, cardiovascular system problems, women do not prefer it due to its difficulties in the application (Suckling J 2003, Cicinelli E 2008).

$1,25(\mathrm{OH})_{2} \mathrm{D}_{3}$ actions on target tissues regulate: protein kinase cascades leading to cell proliferation, differentiation and apoptosis. Protein kinase cascades have been known as mitogen-activated protein kinase (MAPK) signaling cascades. MAPKs regulate cellular responses through the phosphorylation of other kinases, cytoplasmic and membrane proteins and transcription factors. The ERK pathway is a major determinant in the control of cell growth, differentiation and survival (Johansen 2003, Eckert 2002).

The biological effects of 1,25-dihydroxyvitamin $D_{3}\left(1,25(\mathrm{OH})_{2} D_{3}\right)$ are mediated by its nuclear receptor (Petrazzouli 1999). They are expressed in multiple tissues within the body such as liver, kidney, thyroid, adrenal, gastrointestinal tract, breast and skin (Eckert 2002). Vitamin D3 and its receptors form a complex that binds to the vitamin D3 response element of genes, and either positively or negatively affects transcription of some genes (Johansen 2003).

Our results showed that VDR and cornifin $\beta$ epitopes are not present in vaginal epithelium of ovariectomized rats, which is not the case in the presence of estradiol. Exagenous $1_{1} 25(\mathrm{OH})_{2} \mathrm{D}_{3}$ treatment of overioctomized rats has been induced proliferation and thickening and to increase the expression of vitamin $D$ receptor and cornifin $\beta$ in the vaginal epithelium with flattened cells that accumulated in the superficial layers. Both VDR and cornifin $\beta$-receptor have been identified in vaginal epithelium treated vitamin $D_{3}$ while they were neagative in overioctomized vaginal epithelium. VDR mainly localized in basal, suprabasal and apical cell layer implicates the role of VDR with cellular proliferation and differentiation. A slightly positive immunohistochemical staining was observed in basal cell layers although we observed strong expression for cornifin $\beta$ in suprabasal and apical cell layer. Therefore, this made us think that cornifin $\beta$ has an effective role in the differentiation of vaginal epithelium. These results are the first to be shown in vivo up-regulation of the VDR expression in vaginal epithelium in response to vitamin $D_{3}$. The demonstration of induced VDR expression by $1,25(\mathrm{OH})_{2} \mathrm{D}_{3}$ raised a question concerning the role 
of VDR in vaginal differentiation and proliferation. It is likely, that the regulation of proliferation and differentiation of the vaginal epithelium and cornifin $\beta$ expression by vitamin $D_{3}$ and vaginal epithelial cells may be mediated by VDR receptors.

In conclusion, to our knowledge, in vaginal epithelium, this is the first study showing the proliferative effect of $1,25(\mathrm{OH})_{2} \mathrm{D}_{3}$ and VDR up-regulation by vitamin $\mathrm{D}_{3}$. The mechanism of $1,25(\mathrm{OH})_{2} \mathrm{D}_{3}$ induced epithelial interactions may have clinical implications. Estrogen is routinely used for vaginal atrophy, but estrogen treatment is within the initiation and progression of neoplasias of estrogen target organs as mammary gland, endometrium, vagina, and cervix (Redeuilh 2002, Ito 2007, Nair 2005, Deligeoroglou 2003, Salazar 2001, Yue 1998 Beresford 1997, Brisson 1994, Brinton 1993, Jick 1993a, Jick 1993b, Whitehead 1981). In this regard, vitamin $D$ potentially may be a new safe therapeutical agent for vaginal atrophy. Of course the mechanisms underlying vaginal epithelium differentiation and VDR up-regulation by $1,25(\mathrm{OH})_{2} \mathrm{D}_{3}$ remains to be further evaluated.

\section{References}

Arnson $Y$, Amital $H$, Shoenfeld $Y$. Vitamin D and autoimmunity: new aetiological and therapeutic considerations. Ann Rheum Dis 2007; 66:1137-42.

Beresford SA, Weiss NS, Voigt LF, McKnight B. Risk of endometrial cancer in relation to use of oestrogen combined with cyclic progestagen therapy in postmenopausal women. Lancet 1997;15: 349:45861.

Berger U, Wilson P, McClelland RA, Colston K, Haussler MR, Pike JW et al. Immunohistochemical detection of 1,25-dihydroxyvitamin D receptors in normal human tissues. Journal of Clinical Endocrinology and Metabolism 1988;67:607-13.

Bikle D, Teichert A, Hawker N, Xie Z, Oda Y. Sequential regulation of keratinocyte differentiation by $1,25(\mathrm{OH}) 2 \mathrm{D} 3, \mathrm{VDR}$, and its coregulators. Steroid Biochem Mol Biol 2007;103:396-404.

Brinton LA, Hoover RN, The endometrial cancer collaborative group. Estrogen replacement therapy and endometrial cancer risk: unresolved issues, J Obstet Gynecol 1993; 81:265-2.

Brisson J, Morin C, Fortier M, Roy M, Bouchard C, Leclerc J, et al. Risk factors forcervical intraepithelial neoplasia: differences betweenlow- and high-grade lesions. Am J Epidemiol 1994; 140:700-10.

7. Castelo-Branco C, Jes'us Cancelo M, Villero J. Management of post-menopausal vaginal atrophy and atrophic vaginitis. Maturitas 2005;52:46-S52.

Cicinelli E. Intravaginal oestrogen and progestin administration: advantages and disadvantages. Best Pract Res Clin Obstet Gynaecol 2008;22:391-405. Epub 2007 Nov 5.

Darwiche N, Celli G, Sly L, Lancillotti F, De Luca LM. Retinoid status controls the appearance of reserve cells and keratin expression in mouse cervical epithelium. Cancer Res 1993; 1:2287-99.

DeLuca H. Overview of general physiologic features and functions of vitamin D, Am J Clin Nutr 2004; 80:1689-96.

Deligeoroglou E, Michailidis E, Creatsas G. Oral contraceptives and reproductive system cancer. Ann N Y Acad Sci 2003; 997:199-208.

Eckert RL, Efimova T, Dashti SR, Balasubramanian S, Deucher A,
Crish JF, et al. Keratinocyte survival, differentiation, and death: many roads lead to mitogen-activated protein kinase, $\mathrm{J}$ Investig Dermatol Symp Proc 2002; 7:36-40.

Erickson KL, Montagna W. New observations on the anatomical features of the female genitalia. J Am Med WomensAssoc 1972; 27:573-81.

Fischer BK, Margesson LJ. Normal anatomy of the vulva, Genital Skin Disorders, Diagnosis And Treatment. Mosby Publishing, St Louis, 1998:99-107.

Fischer D, Seifert M, Becker S, Ludders D, Cordes T, Reichrath J, et al. 25-Hydroxyvitamin D3 lalpha-Hydroxylase Splice Variants in Breast Cell Lines MCF-7 and MCF-10. Cancer Genomics Proteomics 2007;4:295-300.

Gibbs S, Fijneman, R Wiegant J, Geurts van Kessel Avan de Putte P, Backendorf C. Molecular characterization and evolution of the SPRR family of keratinocyte differentiarion markers encoding small proline- rich proteins. Genomics 1993;16: 630-7.

Gijbels MJ, van der Ham F, van Bennekum AM, Hendriks HF, Roholl PJ.Alterations in cytokeratin expression precede histological changes in epithelia of vitamin A-deficient rats. Cell Tissue Res 1992;268:197-203.

Ginanjar E, Sumariyono, Setiati S, Setiyohadi B. Vitamin D and autoimmune disease. Acta Med Indones 2007;39:133-41.

Gniadecki R. Activation of Raf-mitogen-activated protein kinase signalling pathway by $1 \alpha, 25$-dihydroxyvitamin D3 in normal human keratinocytes, J Invest Dermatol 1996;106;1212-7.

Guzey M, Kitada S, Reed JC. Apoptosis induction by 1 ,25-dihydroxyvitamin D3 in prostate cancer. Mol Cancer Ther 2002;1:667-77.

Henderson HS, Ross RK, Bernstein L. Estrogens as acause of human cancer: the richard and hinda rosenthal foundation award lecture. Cancer Res 1988;48:246.

Henderson IC, Canellos GP. Cancer of the breast: the pastdecade. N Engl J Med 1990; 302:17-30.

Holick MF. Resurrection of vitamin D deficiency and rickets, J Clin Invest 2006;116:2062-72.

Ito K, Utsunomiya H, Yaegashi N, Sasano H. Biological Roles of Estrogen and Progesterone in Human Endometrial Carcinoma New Developments in Potential Endocrine Therapy for Endometrial Cancer Endocr J 2007 sep4.

Jetten AM, Nervi C, Vollberg TM. Control of squamous differentiation in tracheobronchial and epidermal epithelial cells: role of retinoids. $\mathrm{J}$ Natl Cancer Inst Monogr 1992;13:93-100.

Jetten AM, De Luca LM, Nelson K, Schroeder W, BurlingameS \& Fujimoto W. Regulation of cornifin $\alpha$ expression in vaginal and uterine epithelium by estrogen and retinoic acid. Molecular and Cellular Endocrinology 1996;123:7-15.

Jick SS, Walker AM and Jick H. Estrogens, progesterone, and endometrial cancer, Epidemiology 1993;4:20-4.

Jick SS. Combined estrogen and profesterone use and endometrial cancer, Epidemiology 1993;4:384.

Jones IS. A histological assessment of normal vulval skin. Clin Exp Dermatol 1983;8:513-21.

Johansen C, Kragballe K, Henningsen J, Westergaard M, Kristiansen K. Iversel $\alpha, 25$-Dihydroxyvitamin D3 stimulates activator protein 1 DNA-binding activity by a phosphatidylinositol 3-kinase/Ras/ MEK/extracellular signal regulated kinase $1 / 2$ and c-Jun $\mathrm{N}$-terminal kinase 1-dependent increase in C-Fos, Fral, and c-Jun expression in human keratinocytes, J Invest Dermatol 2003;120:561-70.

Kamarashev JA, Vassileva SG. Dermatologic diseases of the vulva. Clin Dermatol 1997;15:53-65.

Kutuzova G D and Deluca HF. Gene expression profiles in rat intestine identify pathways for 1,25-dihydroxyvitamin D3 stimulated calcium absorption and clarify its immunomodulatory properties, Arch. Biochem. Biophys 2004; 432: 152-66.

Lebwohl M, Menter A, Weiss J, Clark SD, Flores J, Powers J, et al. Calcitriol $3 \mathrm{microg} / \mathrm{g}$ ointment in the management of mild to moderate plaque type psoriasis: results from 2 placebo-controlled, multicenter, randomized double-blind, clinical studies. J Drugs Dermatol 2007;6:428-35.

Liu $M$, Lee $M H$, Cohen $M$, Bommakanti M, Freedman LP. Transcriptional activation of the Cdk inhibitor p21 by vitamin D3 leads to the induced differentiation of the myelomonocytic cell line U937. Genes Dev 1996;15;10:142-53. 
Mordan-McCombs S, Valrance M, Zinser G, Tenniswood M, Welsh J. Calcium, vitamin $D$ and the vitamin $D$ receptor: impact on prostate and breast cancer in preclinical models. Nutr Rev 2007;65:131-3.

Mun?oz-de-Toro M, Markey CM, Wadia PR, Luque EH, Rubin BS, Sonnenschein $C$, et al. Perinatal exposure to bisphenol-A alters peripubertal mammary gland development inmice. Endocrinology 2005; 146:4138-47.

Nair HB, Luthra R, Kirma N, Liu YG, Flowers L, Evans D, Tekmal RR. Induction of aromatase expression in cervical carcinomas: effects of endogenous estrogen on cervical cancer cell proliferation. Cancer Res. 2005 Dec 1;65:11164-73.

Notelovitz M, Funk S, Nanavati N, Mazzeo M. Estradiol absorption from vaginal tablets in postmenopausal women. Obstet Gynecol 2002;99:556-62.

Nohales F, Maria Dolores Juli'a Bensaleh H, Belgnaoui FZ, Douira L, Berbiche L, Senouci K, et al. Management of post-menopausal vaginal atrophy and atrophic vaginitis. Ann Endocrinol. 2006;67:57580.

Park WH, Seol JG, Kim ES, Hyun JM, Jung CW, Lee CC, et al. Induction of apoptosis by vitamin D3 analogue EB1089 in NCIH929 myeloma cells via activation of caspase 3 and p38 MAP kinase. Br J Haematol 2000;109:576-83.

Pepper C, Thomas A, Hoy T, Milligan D, Bentley P, Fegan C. The vitamin D3 analog EB1089 induces apoptosis via a p53-independent mechanism involving p38 MAP kinase activation and suppression of ERK activity in B-cell chronic lymphocytic leukemia cells in vitro. Blood 2003;101:2454-60.

Petrazzouli M, Goldsmith LA. Molecular mechanisms of cell signaling. In: Freedberg IM, Eisen AAZ, Wollf K, Austen KF, Goldsmith LA, Katz SI, Fitzpatrick TB, editors. Fitzpatrick's Dermatology in General Medicine, edn V. New York, NY: McGraw Hill. 1999: pp11431.

Pittas AG, Lau J, Hu FB, Dawson-Hughes B. The role of vitamin D and calcium in type 2 diabetes. A systematic review and meta-analysis. J Clin Endocrinol Metab 2007;92:2017-29.

Redeuilh G, Attia A, Mester J, Sabbah M. Transcriptional activation by the estrogen receptor alpha is modulated throughinhibition of cyclin-dependent kinases. Oncogene 2002; 21:5773-82.

Salazar EL, Sojo-Aranda I, Lopez R, Salcedo M. The evidence for an etiological relationship between oral contraceptive use and dysplastic change in cervical tissue. Gynecol Endocrinol 2001;15:23-8.

Suckling J, Lethaby A, Kennedy R. Local oestrogen for vaginal atrophy in postmenopausal women.Cochrane Database Syst Rev. 2003;4:CD001500. Review. Update in: Cochrane Database Syst Rev 2006;CD001500.

Van der Laak JA, de Bie LM, de Leeuw H, de Wilde PC, Hanselaar AG. The effect of Replens on vaginal cytology in the treatment of postmenopausalatrophy: cytomorphology versus computerised cytometry. J Clin Pathol 2002; 55:446-51.

Wadia PR, Vandenberg LN, Schaeberle CM, Rubin BS, Sonnenschein $C$, Soto AM. Perinatal bisphenol A exposure increases oestrogen sensitivity of the mammary gland in diverse mouse strains. Environ Health Perspect 2007;115:592-8.

White JH. Profiling 1,25-dihydroxyvitamin D3-regulated gene expression by microarray analysis, J. Steroid Biochem Mol Biol 2004;8990:239-44

Whitehead MI, Townsend PT, Pryse-Davies J, Ryder T, Lane G, Siddle $\mathrm{NC}$, et al. Effects of estrogens and progestagen on the biochemistry and morphology of the postmenopausal endometrium, N Engl J Med 1981;305:1599-605.

Yildirim B, Abban G, Erdogan BS. Immunohistochemical detection of 1,25 -dihydroxyvitamin $D$ receptor in rat vaginal epithelium. Fertility and Sterility 2004;82:1602-8.

Yue W, Wang JP, Hamilton CJ, Demers LM, Santen RJ. In situ aromatization enhances breast tumor estradiol levels and cellular proliferation. Cancer Res 1998;58:927-32.

Zhu X, Wang B, Zhao G, Gu J, Chen Z, Briantais P, Andres P. An investigator-masked comparison of the efficacy and safety of twice daily applications of calcitriol $3 \mathrm{microg} / \mathrm{g}$ ointment vs. calcipotriol 50 microg/g ointment in subjects with mild to moderate chronic plaquetype psoriasis. J Eur Acad Dermatol Venereol 2007;21:466-72. 